\title{
A Compressive Peak Strength Model for CFRP-Confined Thermal Insulation Materials under Elevated Temperature
}

\author{
Yeou-Fong $\mathrm{Li}^{1}{ }^{1}$, Wai-Keong Sio ${ }^{1}$ and Ying-Kuan Tsai ${ }^{2, *}$ \\ 1 Department of Civil Engineering, National Taipei University of Technology, 1, Section 3, Chung-Hsiao E. Rd., \\ Taipei 10608, Taiwan; yfli@ntut.edu.tw (Y.-F.L.); qoo147896325@gmail.com (W.-K.S.) \\ 2 Department of Environmental Information and Engineering, Chung Cheng Institute of Technology, National \\ Defense University, 75, Shiyuan Rd., Daxi Dist., Taoyuan 335, Taiwan \\ * Correspondence: ccitb04007@ndu.edu.tw
}

Received: 25 November 2019; Accepted: 16 December 2019; Published: 19 December 2019

\begin{abstract}
In this paper, a compressive peak strength model for CFRP-confined thermal insulation materials under elevated temperature was proposed. The thermal insulation material was made by Portland cement with different portions of perlite. The compressive strengths of four different perlite ratios in weight, such as $0 \%, 10 \%, 20 \%$, and $30 \%$ of thermal insulation materials, confined by one-layer, two-layer, and three-layer carbon fiber-reinforced polymer (CFRP) composite materials, were obtained. The test results indicated that the specimen's compressive strength decreased with an increase in the amount of perlite replacement and increased with an increase in the number of CFRP wrapping layers. Based on the test results, a theoretical compressive peak strength model with some parameters was proposed. In the meantime, the compressive strengths of the above four different perlite ratios of thermal insulation materials under elevated temperature, such as ambient temperature, $100{ }^{\circ} \mathrm{C}, 150{ }^{\circ} \mathrm{C}, 200{ }^{\circ} \mathrm{C}, 250{ }^{\circ} \mathrm{C}$, and $300^{\circ} \mathrm{C}$, were obtained. For compression tests of specimens with a fixed amount of perlite, the test results indicated that the specimen's compressive strength decreased with an increase in temperature, highlighting a thermal softening phenomenon. Based on the test results, a compressive peak strength model with a thermal softening parameter was proposed to predict the peak strength under elevated temperature. Finally, a compressive peak strength model for thermal insulation material with CFRP confinement under different elevated temperature was derived, and it achieved acceptable results in comparison to the experimental results.
\end{abstract}

Keywords: peak strength; carbon fiber-reinforced polymer; thermal insulation; perlite; elevated temperature

\section{Introduction}

As a global industry, the petrochemical industry is an inextricable part of our lives as it is a vital material for consumers and high-tech products. Transmission mild steel pipelines are viewed as the most cost-efficient way to transport petroleum products. However, these pipelines are sensitive to corrosion in harsh environments, particularly in the presence of acid, chloride, and sulfur ingress media. The common solution for repairing a damaged steel pipe is to cover it with a patch made of carbon fiber or mineral wool. The current strengthening methods for coating thermal insulation materials on the surface of pipelines still have issues to overcome, especially when the corroded pipeline is installed in a high-temperature environment. A strengthening method for high-temperature steel pipelines was proposed by Li et al. [1], where inorganic insulation materials confined by CFRP composite materials were used to strengthen the damaged pipeline under elevated temperature, as shown in Figure 1. 
To improve the performance of the strengthening method discussed in Reference [1] by mixing with other potential additives, we investigate the effect of elevated temperature and perlite replacement ratio on the performance of CFRP-confined concrete under compression. In addition, a compressive peak strength model for CFRP-confined thermal insulation materials under elevated temperature is proposed.

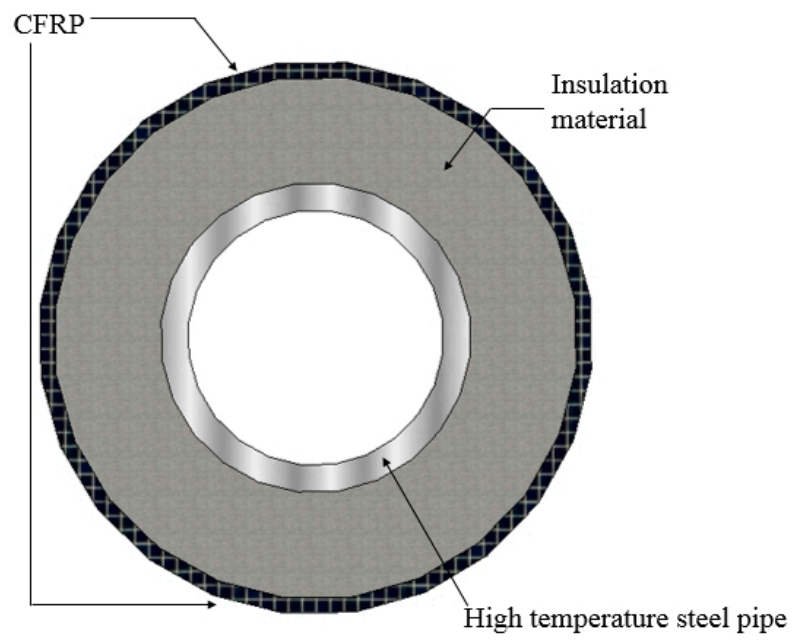

Figure 1. The strengthening method for high-temperature steel pipe.

The advantages of CFRP applications include high strength, anti-corrosion, light weight, and ease of construction. However, it cannot maintain its mechanical properties at high temperatures. Thus, a composite material made from Portland cement, perlite, and CFRP confinement was proposed as a strong and durable solution for repairing metal pipelines. The experimental studies were carried out by conducting compressive strength tests on the specimens made of Portland cement with different ratios of perlite added and under different temperatures. In addition, the CFRP-confined and unconfined specimens were made for compression tests. This study aims at developing a compressive peak strength model for CFRP-confined perlite insulating concrete under elevated temperature. A number of studies were reviewed, and they are summarized below.

The performance of concrete under compression in high-temperature conditions shows that the strength of concrete decreases with an increase in temperature. Calcined perlite powder was added into the concrete for a compression test, and it showed that the compressive strength decreased with the increase in perlite replacement ratio. The thermal conductivity and mechanical performance of lightweight concrete showed that the compressive strength decreased with an increase in the amount of lightweight aggregate [2-4]. The ultra-lightweight cement composite was exposed to high-temperature and showed that elastic modulus loss was significantly quicker than that of compressive strength. Increasing the expanded perlite powder in the lightweight concrete showed that the compressive strength and elastic modulus decreased [5,6].

Some compressive peak strength models were proposed for predicting the peak strength of concrete confined by steel reinforcement and FRP composite materials [7-11]. The behavior of FRP-confined concrete and unconfined specimens exposed to elevated temperatures resulted in concrete losses as the rate of temperature increased. The properties affecting the behavior of FRP-confined concrete and the confinement effectiveness decreased with an increase in the compressive strength of concrete [12-14].

Perlite is a construction material used for heat insulation. Upon adding different percentages of perlite, the compressive strength decreased with an increase in the perlite ratio of the heat insulation materials $[15,16]$. The compressive strength of the concrete increased upon the replacement of expanded perlite and pumice aggregates. By adding bottom ash in the lightweight concrete, the compressive strength and thermal conductivity increased, while it decreased upon adding aluminum. The material 
density and compressive strength decreased following the introduction of expanded perlite aggregates, pumice aggregates, and rubber aggregates into the concrete [17-19].

The CFRP and fibre reinforced cementitious matrix (FRCM) elements at elevated temperatures in the climatic chamber and the load-bearing capacity gradually decreased with an increase in temperature [20,21]. For the compressive behavior of concrete cylinders confined by CFRP composite material, the compressive strength increased upon using CFRP composite jackets. The compressive strength of a square reinforced concrete column increased by wrapping it with CFRP composite materials. The CFRP-enclosed concrete cylinders had an obvious size effect under varying CFRP confinement ratios, and the degree of CFRP confinement could significantly improve the strength [22-25].

\section{Experimental Program}

In this paper, the experimental program involved the concrete mix test and compressive strength test to investigate the impact of high temperature on the efficiency of externally confined thermal insulation material with CFRP sheets. Thus, the peak strength for different numbers of wrapping layers of CFRP under certain elevated temperatures was proposed.

\subsection{Materials}

The materials used in this research included Portland cement, expanded perlite, carbon-fiber sheets, and epoxy. Portland cement is a general-purpose cement suitable for all uses; it is composed of calcium, silicon, aluminum, iron, and small amounts of other compounds. Due to its characteristics of high hydration heat, low early strength, and long curing time, it is generally used in infrastructure construction.

Expanded perlite is an amorphous volcanic glass, and it is composed of about $70 \%$ silicon dioxide and $14 \%$ alumina. When it is heated above $870{ }^{\circ} \mathrm{C}$, the volume increases to $4-20$ times its original volume and becomes porous, which is called expanded perlite. Its characteristic of porosity makes it a good insulation material, and it is widely used in building construction, agriculture, and chemical engineering fields. The grain size of the expanded perlite powder used in this study ranged from $1 \mathrm{~mm}$ to $6 \mathrm{~mm}$, as shown in Figure 2a.

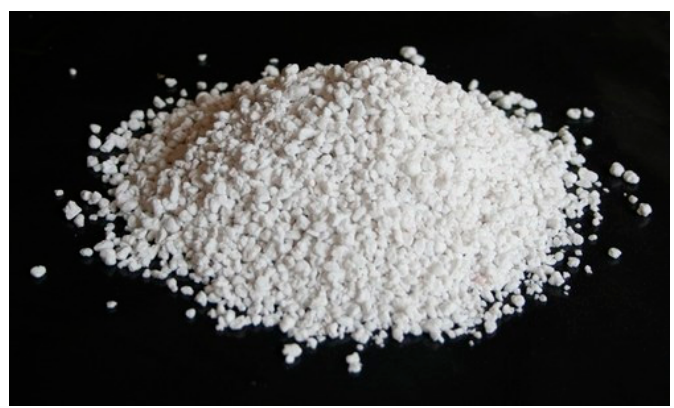

(a)

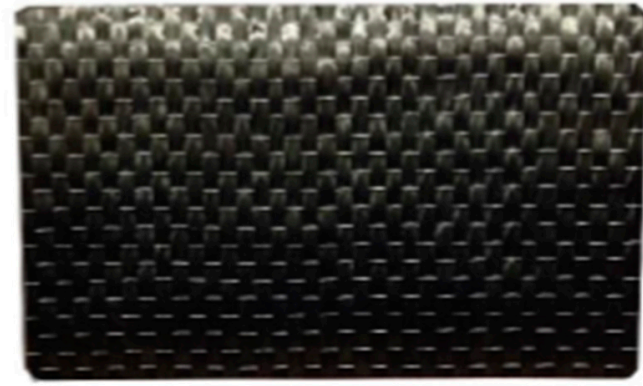

(b)

Figure 2. Expanded perlite powder (a) and carbon fiber-reinforced polymer (CFRP) (b).

CFRP is made of a polymer matrix reinforced with carbon fibers, and it is a composite material. Recently, carbon fiber was widely used in automotive, aerospace, and civil engineering applications. The CFRP composite material has features of acid and alkali resistance, anti-corrosion, and a high strength-to-weight ratio [26]. The material properties of the carbon-fiber sheet and epoxy resin are shown in Table 1. The CFRP sheet used in the present study was a uni-directional one to provide better confinement performance, as shown in Figure 2b. 
Table 1. Material properties of the carbon-fiber sheet and epoxy resin.

\begin{tabular}{ccc}
\hline \multirow{3}{*}{ Carbon-Fiber Sheet } & Specification & FAW $300\left(\mathrm{~g} / \mathbf{m}^{\mathbf{2}}\right)$ \\
\cline { 2 - 3 } & Young's modulus, $E_{c f}(\mathrm{GPa})$ & 250 \\
\cline { 2 - 3 } & Tensile strength $(\mathrm{GPa})$ & 4.9 \\
\cline { 2 - 3 } & Thickness $(\mathrm{mm} / \mathrm{layer})$ & 0.16 \\
\cline { 2 - 3 } Epoxy Resin & Ultimate strain & 0.02 \\
\cline { 2 - 3 } & Viscosity (cps) & 3.5 \\
\cline { 2 - 3 } & Toung's modulus $(\mathrm{GPa})$ & 52.2 \\
\cline { 2 - 3 } & Tensile strength $(\mathrm{MPa})$ & 10.5 \\
\hline
\end{tabular}

\subsection{Samples and Testing Procedure}

This study conducted cylindrical specimen compressive testing under ambient temperature in accordance with the ASTM C39/C39M-18 [27], which entailed placing specimens in a universal testing machine, with each specimen at a loading rate of $900-1800 \mathrm{~N} / \mathrm{s}$ (strain rate of $10^{-6} / \mathrm{s}$ to $10^{-4} / \mathrm{s}$ ) to obtain the maximum compressive strength at its seven-day curing age. This test program was undertaken by the 100-ton force universal testing machine at the material laboratory of the Department of Civil Engineering, National Taipei University of Technology.

In addition, the perlite powders were added to Portland cement with four perlite ratios based on weight $(0 \%, 10 \%, 20 \%$, and $30 \%)$, and the water-cement ratio for Portland cement was 0.4 . Then, the compressive strength of cubic specimens was obtained under different temperatures (ambient temperature, $100{ }^{\circ} \mathrm{C}, 150{ }^{\circ} \mathrm{C}, 200{ }^{\circ} \mathrm{C}, 250{ }^{\circ} \mathrm{C}$, and $300{ }^{\circ} \mathrm{C}$ ) at the 28 -day curing age with the same controlled loading rate. The specimens were placed in a crucible and heated in a furnace, and then they were removed from the furnace for compressive strength test immediately after reaching the required temperature. The compressive strength tests of standard cubic specimens with dimensional aspects of $5 \mathrm{~cm} \times 5 \mathrm{~cm} \times 5 \mathrm{~cm}$ were performed according to ASTM C109/C M109-02 [28]. Table 2 gives the name of the specimens and testing methods, and Table 3 lists the mix design proportions for insulating material specimens. In Table 2, CPC stands for the cement with perlite specimen for compression test, CPCC stands for the cement with perlite specimen confined by CFRP composite material for compression test, and CPTC stands for the cement with perlite specimen under elevated temperature for compression test.

Table 2. Identification of unconfined specimens. CFRP—carbon fiber-reinforced polymer.

\begin{tabular}{cccc}
\hline Specimen & $\begin{array}{c}\text { Description } \\
\text { (Test Method) }\end{array}$ & Dimension & Perlite Ratio in Weight (\%) \\
\hline \multirow{2}{*}{ CPC } & $\begin{array}{c}\text { Cement with perlite } \\
\text { (ASTM C39/C39M-18) }\end{array}$ & $\Phi 10 \mathrm{~cm} \times 20 \mathrm{~cm}$ & $0 ; 10 ; 20 ; 30$ \\
\cline { 2 - 3 } CPCC & $\begin{array}{c}\text { Cement with perlite } \\
\text { confined by CFRP } \\
\text { (ASTM C39/C39M-18) }\end{array}$ & $\Phi 10 \mathrm{~cm} \times 20 \mathrm{~cm}$ & \\
\cline { 2 - 3 } CPTC & $\begin{array}{c}\text { Cement with perlite } \\
\text { under elevated } \\
\text { temperature (ASTM } \\
\text { C109/C M109-02) }\end{array}$ & $5 \mathrm{~cm} \times 5 \mathrm{~cm} \times 5 \mathrm{~cm}$ & \\
\hline
\end{tabular}


Table 3. Applied mix design for insulating material specimens.

\begin{tabular}{ccccc}
\hline Specimen & Perlite (g) & Perlite Ratio \% (in Weight) & Portland Cement (g) & Water (g) \\
\hline CPC0 & 0 & 0 & 2000 & 800 \\
CPC10 & 200 & 10 & 1800 & 720 \\
CPC20 & 400 & 20 & 1600 & 640 \\
CPC30 & 600 & 30 & 1400 & 560 \\
\hline
\end{tabular}

The other measuring apparatus employed in this study included an infrared thermometer (measurement range from $-35^{\circ} \mathrm{C} \sim 550{ }^{\circ} \mathrm{C}$ ), a strain gauge (elongation limit up to $2 \%$ ), and a data acquisition system. The identification and the number of cylinders and cubic specimens are listed in Tables 4 and 5, respectively.

Table 4. Number of cylindrical specimens with different numbers of CFRP layers.

\begin{tabular}{|c|c|c|c|c|}
\hline Specimen & Shape & Perlite Ratio in Weight (\%) & No. of CFRP Layers & No. of Cylindrical Specimens \\
\hline $\mathrm{CPCO}$ & \multirow{4}{*}{ Cylinder } & 0 & \multirow{4}{*}{$0,1,2,3$} & 12 \\
\hline СРC10 & & 10 & & 12 \\
\hline СРC20 & & 20 & & 12 \\
\hline СРС 30 & & 30 & & 12 \\
\hline
\end{tabular}

Total number of specimens: 48 .

Table 5. Number of cubic specimens under elevated temperatures.

\begin{tabular}{|c|c|c|c|c|}
\hline Specimen & Shape & Perlite Ratio in Weight (\%) & Elevated Temperatures $\left({ }^{\circ} \mathrm{C}\right)$ & No. of CFRP Cubic Specimen \\
\hline СРТC0 & & 0 & & 12 \\
\hline СРТС10 & Cube & 10 & 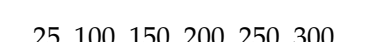 & 12 \\
\hline СРТС20 & Cube & 20 & $20,100,100,200,230,000$ & 12 \\
\hline СТРС30 & & 30 & & 12 \\
\hline
\end{tabular}

Forty-eight cylindrical specimens $(10 \mathrm{~cm}$ in diameter and $20 \mathrm{~cm}$ in height) were tested to investigate the effect of CFRP wrapping on the compressive strength of insulation materials. The unconfined and CFRP-confined specimens (one, two, and three layers of CFRP) were tested considering four different ratios of perlite replacement based on weight $(0 \%, 10 \%, 20 \%$, and $30 \%)$.

The applied procedures of CFRP attachment are described below. The surface was cleaned before applying CFRP layers with an epoxy-based coating to ensure a good bond between the outer surface of the cylinders and CFRP. A thin layer of primer epoxy was firstly applied to the surface of the cylinders. After the primer epoxy was cured at ambient temperature for several hours, the carbon-fiber sheet was applied to the cylinders. For each layer of carbon-fiber sheet, the epoxy was applied using a paintbrush to fully saturate the carbon fiber. After the required sheet layers were applied, the CFRP jacketing was cured at ambient temperature. The length of the overlay was more than $10 \mathrm{~cm}$, and the duration of applying the next layer was more than one day. The CFRP tension strain was measured by circumferential strain gauges glued to the middle surface of the CFRP-wrapped specimens, and the elongation limit of the strain gauges was as high as $2 \%$. The compression test for a concrete cylinder confined by CFRP composite material is shown in Figure 3. 


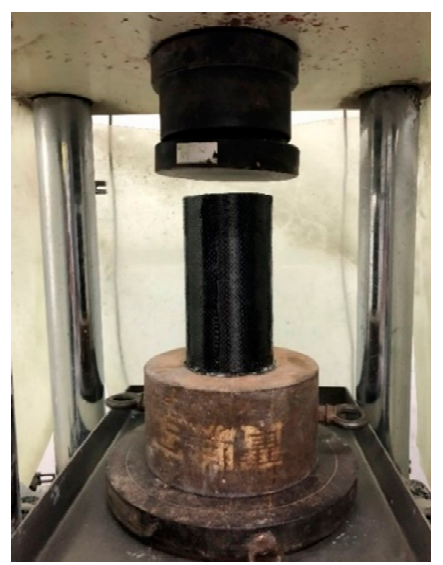

Figure 3. Compression test for cylindrical concrete confined by CFRP composite material.

\section{Compression Test of the Insulation Material Confined by CFRP}

The compression test results of the insulation material without/with CFRP are described in the subsections below. The experiment aimed at investigating the effect of perlite additions (ratios in weight: $0 \%, 10 \%, 20 \%$, and $30 \%$ ) on the compressive strength of the specimens.

\subsection{Compression Test on Specimens without CFRP Wrapping}

A series of compression tests on the unconfined cylindrical specimens were carried out to observe the change in strength with different mix designs. Table 6 shows the test results, and the results showed that the compressive strength decreased with an increase in perlite addition. As seen from Table 6 , the strength of Portland specimens with $10 \%$ perlite was less than half that of the pure cement specimen. The compressive strengths of the cylindrical unconfined specimens changed according to different perlite content, as shown in Figure 4. Figure 5 shows the failure modes of the specimens after testing. For lower perlite ratios of the specimen, the failure mode was a brittle failure.

Table 6. Compression test results of CFRP-confined specimens with perlite addition.

\begin{tabular}{cccc}
\hline Specimen & Perlite Ratio in Weight (\%) & Average Compressive Strength (MPa) & Decrease Percentage (\%) \\
\hline CPC0 & 0 & 42.75 & - \\
\hline CPC10 & 10 & 18.42 & 56.91 \\
\hline CPC20 & 20 & 12.11 & 71.67 \\
\hline CPC30 & 30 & 7.50 & 82.46 \\
\hline
\end{tabular}

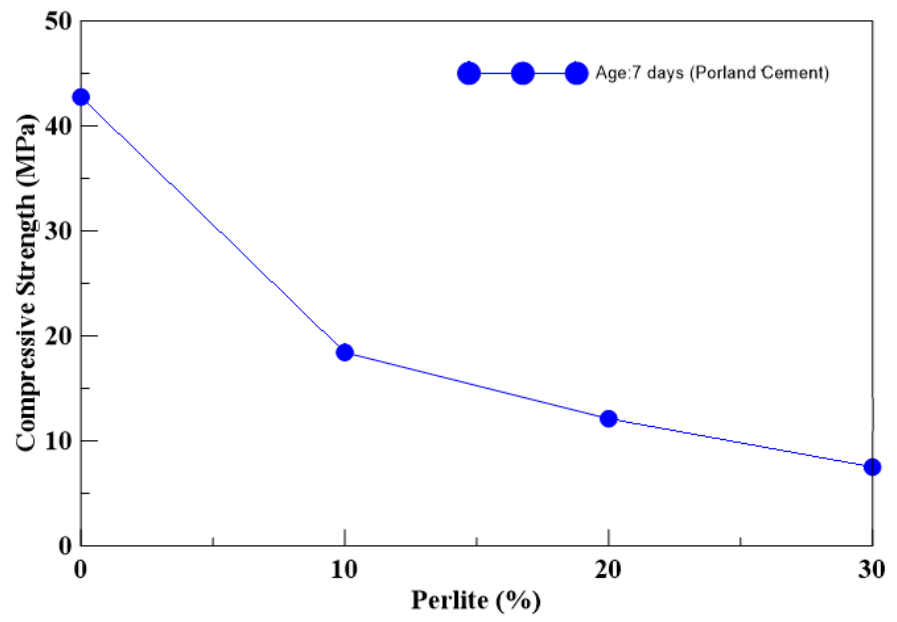

Figure 4. Compressive strength of the cylindrical specimens with different perlite ratios. 


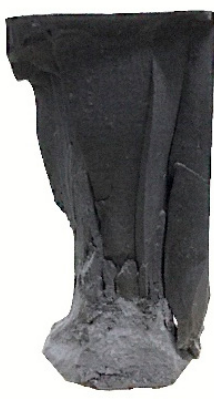

(a)

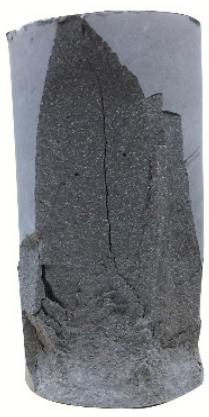

(b)

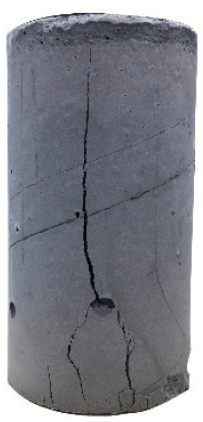

(c)

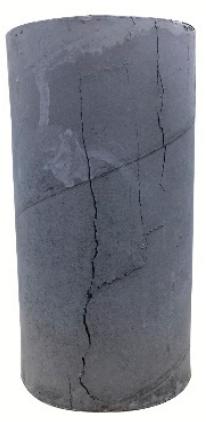

(d)

Figure 5. Failure modes of the unconfined cylindrical specimens after compression test, (a) CPC0; (b) CPC10; (c) CPC20; (d) CPC30.

\subsection{Compression Test on CFRP-Confined Specimens}

The compression test on the CFRP-confined specimens with four perlite ratios in weight $(0 \%, 10 \%$, $20 \%$, and $30 \%$ ) was conducted to observe the effect of the number of wrapping layers.

\subsubsection{Portland Cement with $0 \%$ Perlite}

To study the effect of perlite addition on the compressive peak strength of Portland cement cylinders wrapped with different numbers if CFRP layers, a compression test on specimens with $0 \%$ perlite addition was conducted as a control group. Figure 6a illustrates the axial stress versus the axial strains for the unwrapped cylinders; the average ultimate strength was $42.75 \mathrm{MPa}$. As seen in Figure $6 \mathrm{~b}-\mathrm{d}$, the compressive peak strengths of the specimens CPCC0_1, CPCC0_2, and CPCC0_3 were increased by $67-202 \%$ with an increase in the number of CFRP wrapping layers.

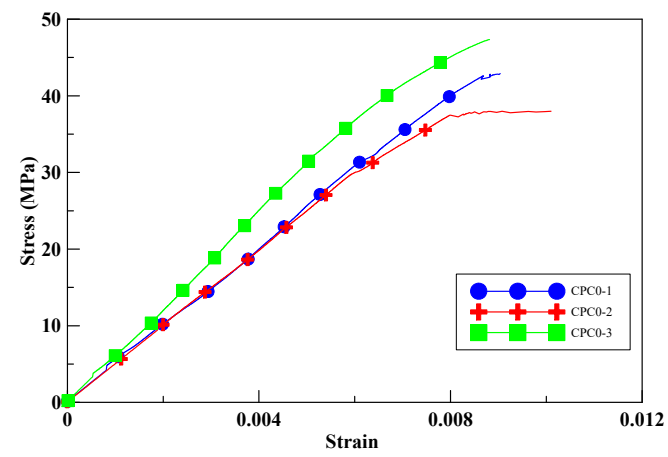

(a)

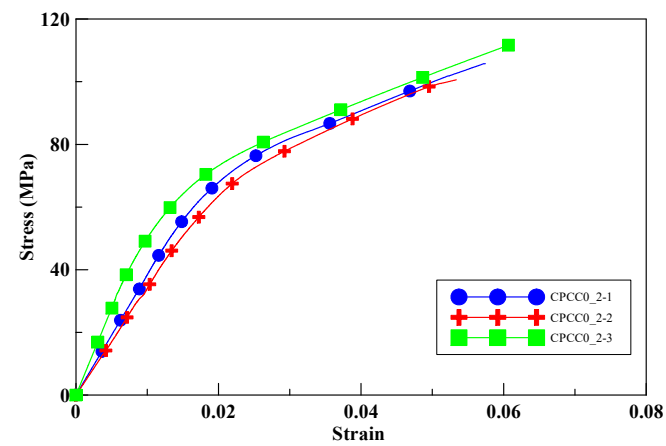

(c)

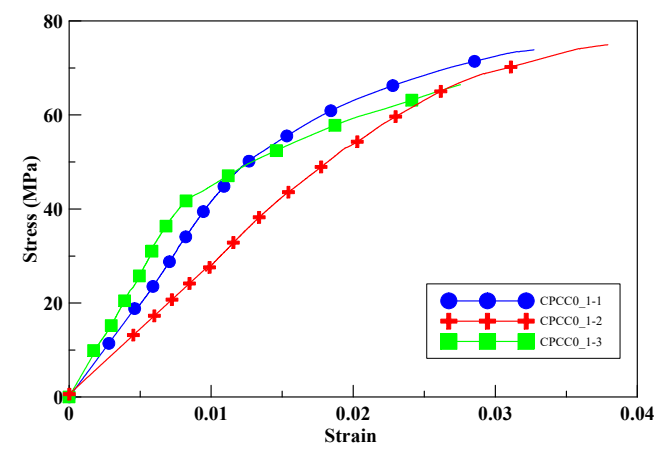

(b)

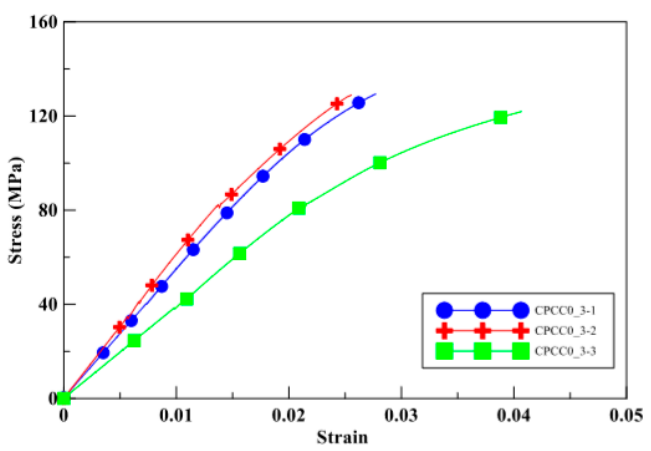

(d)

Figure 6. Experimental stress-strain curves for test specimens with $0 \%$ perlite, (a) unconfined; (b) one-layer CFRP; (c) two-layer CFRP; (d) three-layer CFRP. 
Moreover, the ultimate strain of CPCC0_1 and CPCC0_2 was increased by $259-520 \%$. These improvements illustrate the confinement effect on the compressive strength enhanced by CFRP. The ultimate strain improvement of CPCC0_3 was less than that of CPCC0_2, which may be attributed to the stronger confinement strength that constrained the deformation before failure, leading to brittle failure. In CPCC0_2, it should be noted that an abrupt drop in strength occurred when loaded at about $60 \mathrm{MPa}$ due to part of the CFRP composites rupturing; the strength was regained until a full rupture of CFRP occurred. Table 7 shows the fractured specimens at failure, and Table 8 shows the average compressive peak strengths and their corresponding increase percentages.

Table 7. Appearance of the CFRP-confined specimens after testing.

\begin{tabular}{|c|c|c|c|}
\hline $\begin{array}{l}\text { Specimen with Perlite } \\
\text { Percentage }(\%)\end{array}$ & 1-Layer CFRP & 2-Layer CFRP & 3-Layer CFRP \\
\hline $0 \%$ perlite $(\mathrm{CPC} 0)$ & & & \\
\hline $10 \%$ perlite $(\mathrm{CPC} 10)$ & & & \\
\hline $20 \%$ perlite (CPC20) & & & \\
\hline $30 \%$ perlite $(\mathrm{CPC} 30)$ & & & \\
\hline
\end{tabular}


Table 8. Compression test results of specimens with perlite addition confined by different numbers of layers of CFRP.

\begin{tabular}{|c|c|c|c|c|}
\hline Specimen & $\begin{array}{l}\text { Perlite Ratio in } \\
\text { Weight (\%) }\end{array}$ & $\begin{array}{l}\text { No. of CFRP } \\
\text { Layers }\end{array}$ & $\begin{array}{l}\text { Average Compressive } \\
\text { Peak Strength (MPa) }\end{array}$ & $\begin{array}{c}\text { Increase } \\
\text { Percentage (\%) }\end{array}$ \\
\hline СРC0 & \multirow{4}{*}{0} & - & 42.75 & - \\
\hline CPCC0_1 & & 1 & 71.76 & 67.4 \\
\hline CPCC0_2 & & 2 & 106.18 & 148.4 \\
\hline СPCCO_3 & & 3 & 129.32 & 202.5 \\
\hline CPC10 & \multirow{4}{*}{10} & - & 18.42 & - \\
\hline CPCC10_1 & & 1 & 42.48 & 130.6 \\
\hline CPCC10_2 & & 2 & 55.71 & 202.4 \\
\hline СРCC10_3 & & 3 & 79.33 & 330.7 \\
\hline СРC20 & \multirow{4}{*}{20} & - & 12.11 & - \\
\hline CPCC20_1 & & 1 & 37.73 & 211.6 \\
\hline CPCC20_2 & & 2 & 47.51 & 292.3 \\
\hline СРСC20_3 & & 3 & 62.58 & 416.8 \\
\hline СРС 30 & \multirow{4}{*}{30} & - & 7.50 & - \\
\hline СРСС30_1 & & 1 & 29.67 & 295.6 \\
\hline СРСС $30 \_2$ & & 2 & 43.92 & 485.6 \\
\hline СРСС $30 \_3$ & & 3 & 49.40 & 558.7 \\
\hline
\end{tabular}

\subsubsection{Portland Cement with $10 \%$ Perlite}

The average compressive peak strength of the unwrapped cylinders with a $10 \%$ perlite additive was $18.42 \mathrm{MPa}$, as shown in Figure 7a. With an increase in the number of CFRP wrapping layers, the compressive strength of the specimens CPCC10_1, CPCC10_2, and CPCC10_3 was increased by $131-331 \%$, as shown in Figure $7 \mathrm{~b}-\mathrm{d}$. The confinement effect on compressive peak strength improvement was more significant than for the specimens without perlite additive.

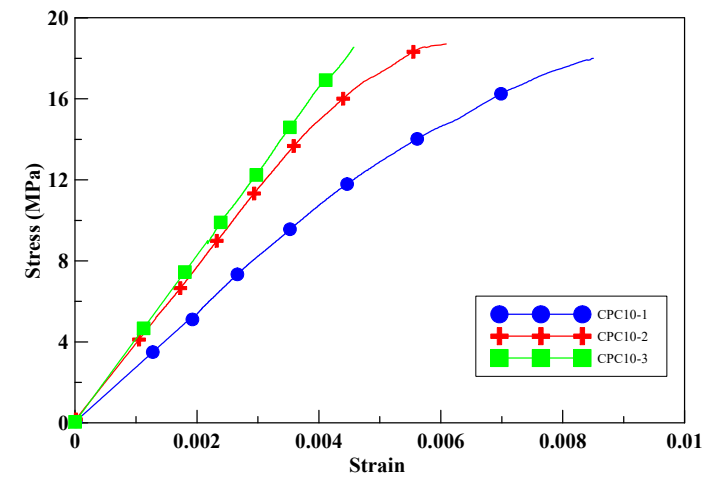

(a)

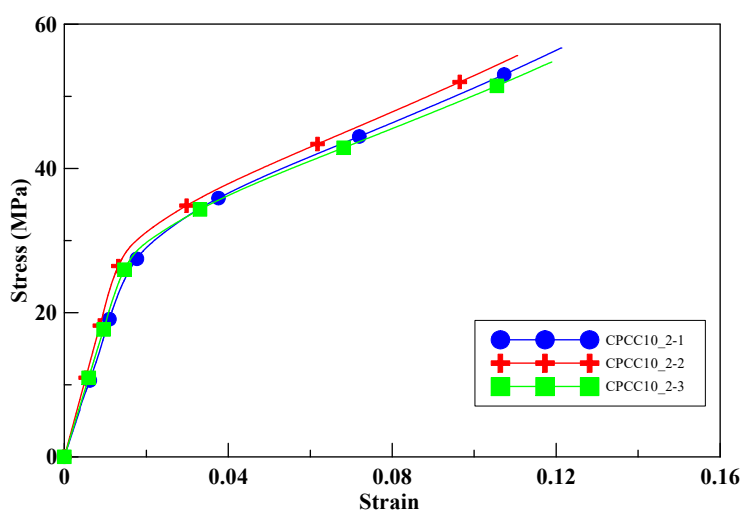

(c)

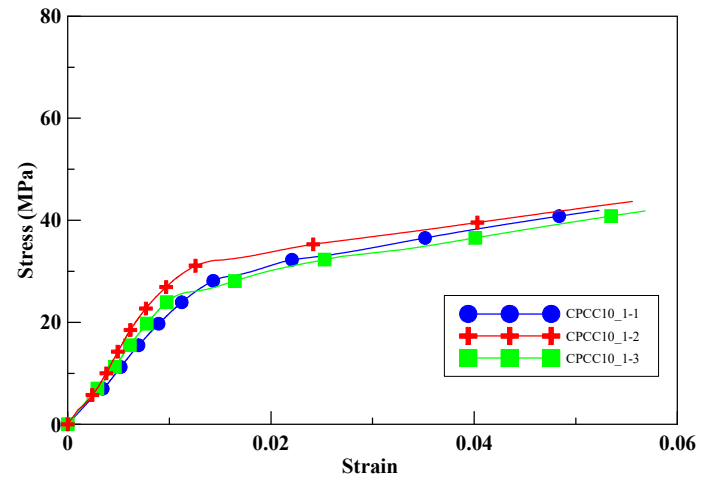

(b)

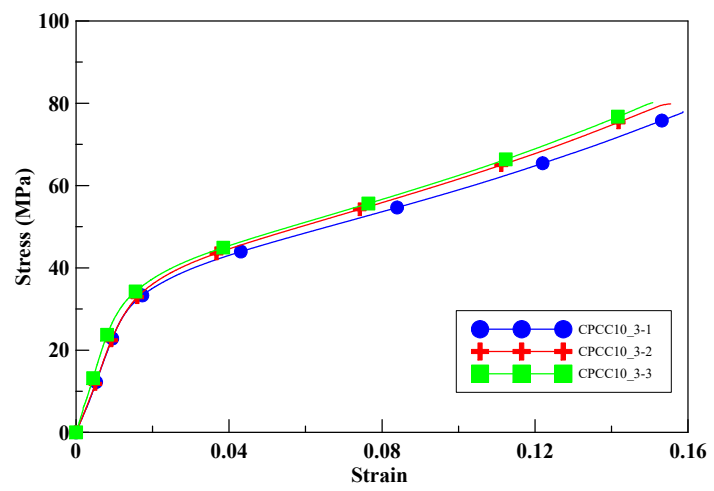

(d)

Figure 7. Experimental stress-strain curves for test specimens with $10 \%$ perlite, (a) unconfined; (b) one-layer CFRP; (c) two-layer CFRP; (d) three-layer CFRP. 


\subsubsection{Portland Cement with $20 \%$ Perlite}

With $20 \%$ perlite replacement, the compressive strength of the unwrapped specimens was decreased by $71.67 \%$ compared to the unconfined specimens without CFRP, as shown in Figure $8 \mathrm{a}$. As seen from Figure $8 \mathrm{~b}-\mathrm{d}$, the compressive peak strengths of the specimens CPCC20_1, CPCC20_2, and CPCC20_3 were increased by $211-416 \%$ with an increase in the number of CFRP wrapping layers. It is again illustrated that, at a given ratio of perlite addition, the compressive peak strength increased with the number of CFRP wrapping layers.

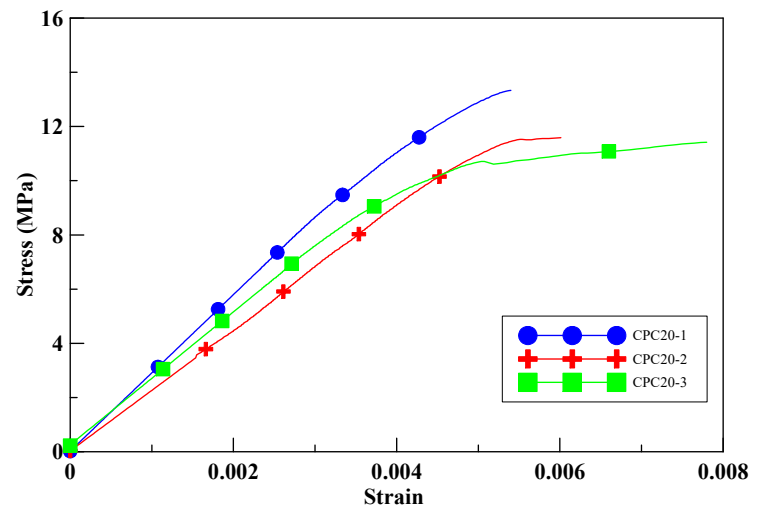

(a)

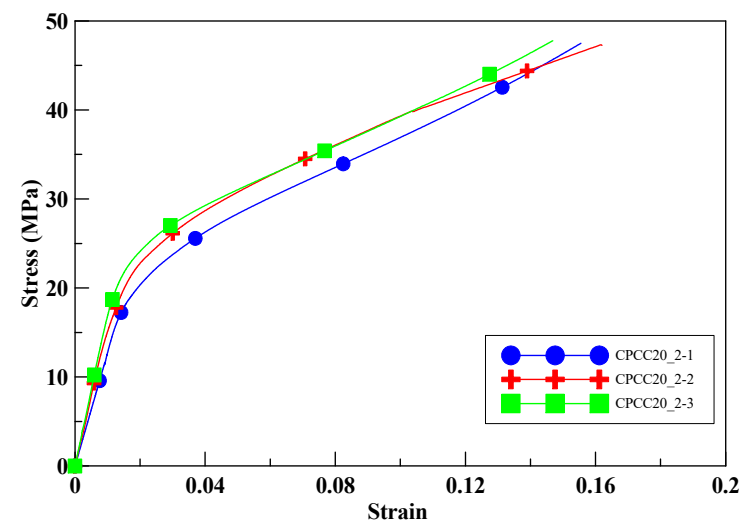

(c)

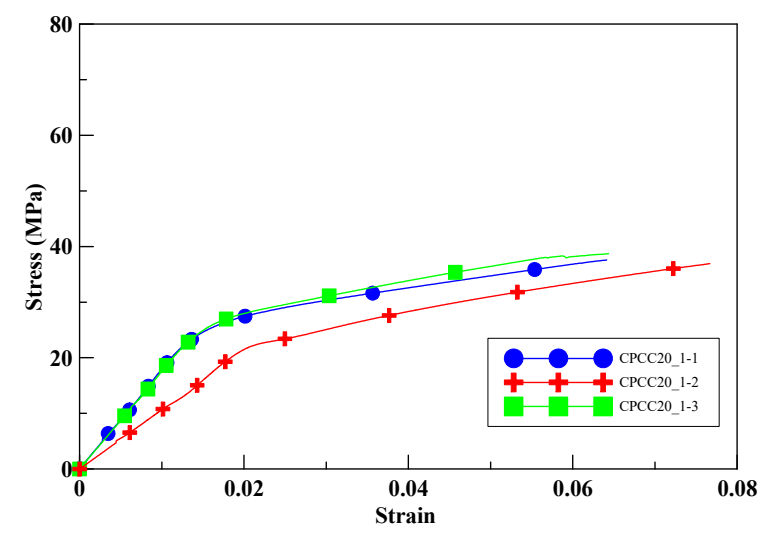

(b)

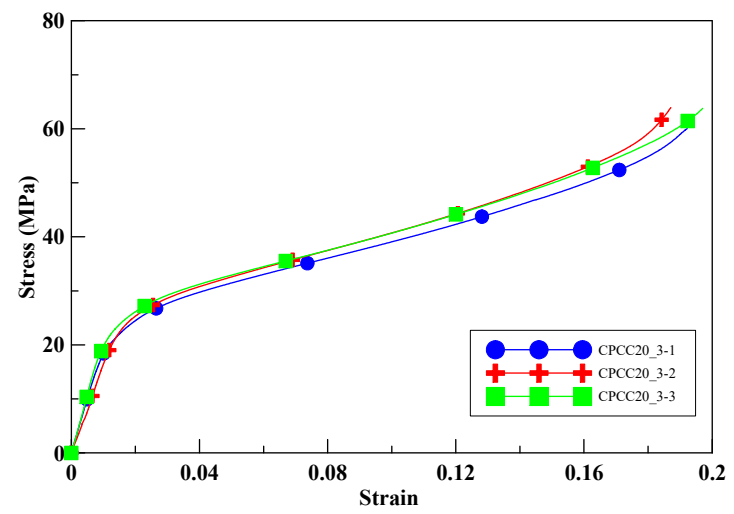

(d) three-layer CFRP

Figure 8. Experimental stress-strain curves for test specimens with $20 \%$ perlite, (a) unconfined; (b) one-layer CFRP; (c) two-layer CFRP; (d) three-layer CFRP.

\subsubsection{Portland Cement with $30 \%$ Perlite}

When the perlite additive increased to $30 \%$, the ultimate strength of the unconfined cylinders decreased to 7.5 MPa, as shown in Figure 9a. With an increase in the perlite addition, the compressive strength decreased. With an increase in the number of CFRP confined layers, the compressive strength of the specimens CPCC30_1, CPCC30_2, and CPCC30_3 was increased by 296-559\%, as shown in Figure $9 \mathrm{~b}-\mathrm{d}$. The improvement percentage of the specimens was the most significant among the four groups of specimens with different amounts of perlite additives. This trend illustrates that the compressive strength enhanced by CFRP was more effective in specimens with relatively low strength. It should be noted that, in CPCC30_3, a strength loss could be observed on the stress-strain curves at about $10 \mathrm{MPa}$, indicating the damage of the CFRP composite. It reached the peak strength when the CFRP completely ruptured and failed to carry the extra load. Moreover, the hoop tension provided by three layers of CFRP wrapping was stronger than the compressive strength of the core part of the specimens. Thus, it allowed the specimens to withstand more load. It was observed that, 
for all CFRP-confined specimens, the failure was due to the rupture of CFRP composite materials, accompanied by a loud sound.

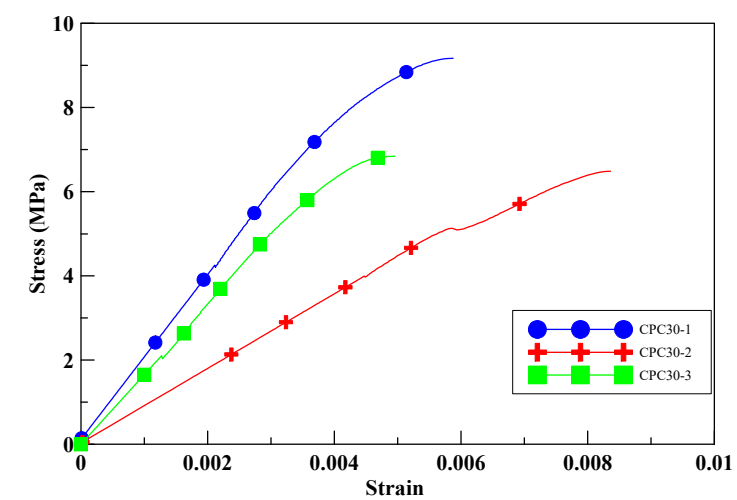

(a)

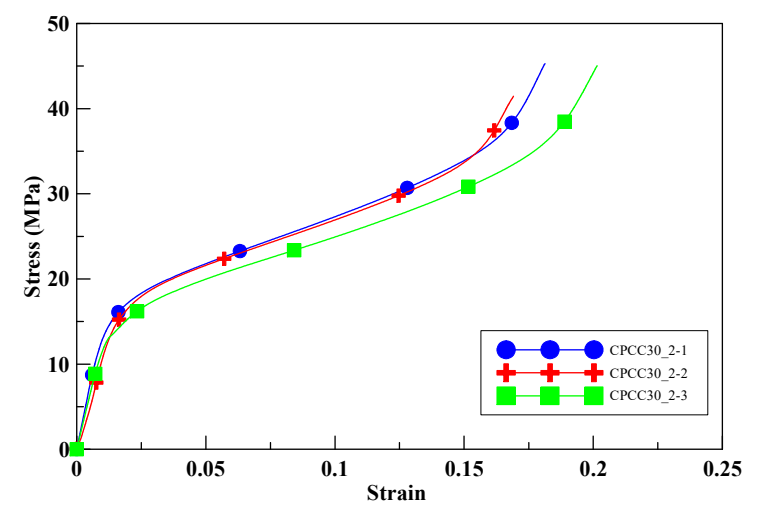

(c)

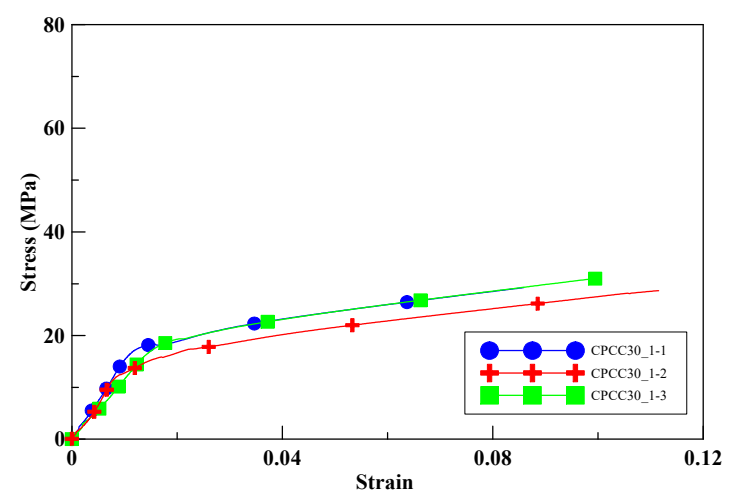

(b)

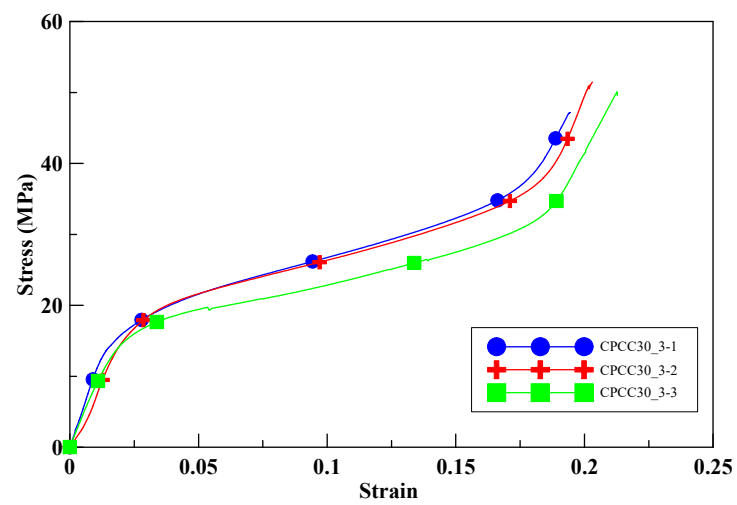

(d)

Figure 9. Experimental stress-strain curves for test specimens with $30 \%$ perlite, (a) unconfined; (b) one-layer CFRP; (c) two-layer CFRP; (d) three-layer CFRP.

\subsection{Discussion on CFRP-Confined Specimen Compression Test Results}

From the above test results, the compressive peak strength of the insulation material specimens increased due to confinement by different numbers of layers of CFRP composite material, as compared to those specimens without confinement. Table 8 shows the compressive peak strengths of the insulation material specimens and their increase percentages. As the number of layers of CFRP wrapping increased, so did the percentage of compressive peak strength.

\section{Compressive Test Results of the Insulation Material at Elevated Temperature}

This experiment aimed at investigating the effect of perlite addition (ratios in weight: $0 \%, 10 \%$, $20 \%$, and $30 \%$ ) on the residual compressive strength of the insulating material specimens under different temperatures (ambient temperature $=25^{\circ} \mathrm{C}, 100{ }^{\circ} \mathrm{C}, 150{ }^{\circ} \mathrm{C}, 200{ }^{\circ} \mathrm{C}, 250{ }^{\circ} \mathrm{C}$, and $300{ }^{\circ} \mathrm{C}$ ). The compressive strength test was applied to standard cubic specimens with dimensional aspects of $5 \mathrm{~cm} \times 5 \mathrm{~cm} \times 5 \mathrm{~cm}$. A series of compression tests on cubic specimens with different mix designs under elevated temperatures were conducted to observe the changes in strength after 28-day curing age. The specimens were placed in a crucible and heated, and then they were removed from the furnace to cool down; when they reached the required temperature, the compressive strength tests were conducted immediately. The peak strength decreased with an increase in temperature. The compressive stress-temperature relationships of the specimens are shown in Figure 10. As shown in Table 9, the results indicated that the insulating material specimens' compressive peak strength decreased with an increase in perlite addition. 


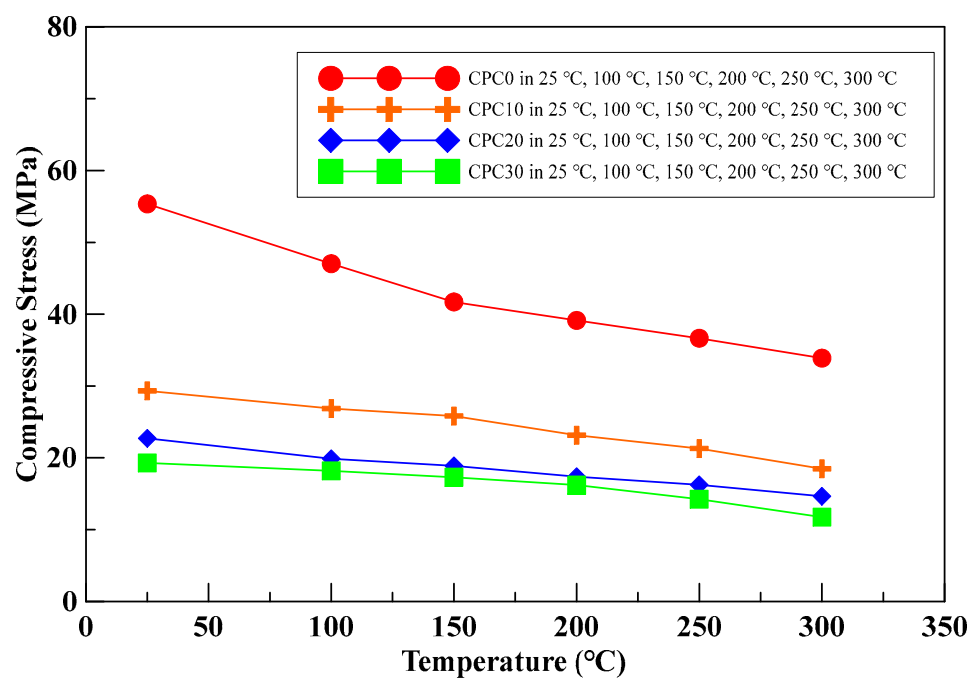

Figure 10. Compressive strength of the insulating material specimens with various perlite ratios and temperatures.

Table 9. Results of unconfined specimens at different elevated temperatures.

\begin{tabular}{|c|c|c|c|}
\hline Specimen & Temperature & Perlite Ratio in Weight & $\begin{array}{l}\text { Average Compressive } \\
\text { Peak Strength (MPa) }\end{array}$ \\
\hline СРТ25C0 & \multirow{4}{*}{$25^{\circ} \mathrm{C}$ (room temperature) } & $0 \%$ & 55.25 \\
\hline СРТ25С10 & & $10 \%$ & 29.33 \\
\hline СРТ25С20 & & $20 \%$ & 22.70 \\
\hline СРТ25С30 & & $30 \%$ & 19.29 \\
\hline СРТ100С0 & \multirow{4}{*}{$100^{\circ} \mathrm{C}$} & $0 \%$ & 47.02 \\
\hline CPT100C10 & & $10 \%$ & 26.82 \\
\hline СРТ100C20 & & $20 \%$ & 19.86 \\
\hline СРТ100С30 & & $30 \%$ & 18.17 \\
\hline СРТ150С0 & \multirow{4}{*}{$150^{\circ} \mathrm{C}$} & $0 \%$ & 41.70 \\
\hline CPT150C10 & & $10 \%$ & 25.83 \\
\hline СРT150С20 & & $20 \%$ & 18.89 \\
\hline СРT150С 30 & & $30 \%$ & 17.29 \\
\hline СРТ200C0 & \multirow{4}{*}{$200^{\circ} \mathrm{C}$} & $0 \%$ & 39.13 \\
\hline СРТ200C10 & & $10 \%$ & 23.15 \\
\hline СРТ200С20 & & $20 \%$ & 17.38 \\
\hline СРТ200С30 & & $30 \%$ & 16.20 \\
\hline СРТ250C0 & \multirow{4}{*}{$250^{\circ} \mathrm{C}$} & $0 \%$ & 36.65 \\
\hline CPT250C10 & & $10 \%$ & 21.30 \\
\hline СРТ250С20 & & $20 \%$ & 16.25 \\
\hline СРТ250С 30 & & $30 \%$ & 14.24 \\
\hline СРТ300С0 & \multirow{4}{*}{$300^{\circ} \mathrm{C}$} & $0 \%$ & 33.87 \\
\hline СРТ300С10 & & $10 \%$ & 18.48 \\
\hline СРТ300С20 & & $20 \%$ & 14.65 \\
\hline СРТ300С30 & & $30 \%$ & 11.42 \\
\hline
\end{tabular}

The comparison results indicated that the ratio of perlite in weight plays a significant role in the efficiency of insulation material specimens under elevated temperatures. For compression tests of specimens under a given temperature, higher ratios of perlite addition in weight led to lower compressive strength. Moreover, for compression tests of specimens with a fixed amount of perlite, a higher temperature led to a lower compressive strength. 


\section{Compressive Peak Strength Model}

This study developed a peak strength model suitable to represent the compressive behavior of insulation material specimens under different temperatures confined with different numbers of CFRP wrapping layers using regression analysis of the test data. The thermal softening parameter of the peak strength was obtained from the experimental results. The peak strength of the insulation materials confined by CFRP was derived from the Mohr-Columb failure envelope theory, which can be explicitly expressed as a function of the strength of unconfined insulation material, the lateral confining stress, and the angle of internal friction of insulation material. A combined peak strength model of thermal insulation material with CFRP confinement under elevated temperature is proposed. Comparing the peak strengths of the proposed model with that of the experimental results, it was found that the proposed model can predict the peak strength of the perlite insulation material with acceptable accuracy. It is noted that the CFRP-confined specimens were tested at room temperature, and the influence of the temperature on CFRP properties was not taken into account. The derivation and analysis procedure is described below.

\subsection{A Peak Strength Model for CFRP-Confined Insulation Material}

To investigate the effect of CFRP confinement on the strength of insulation material, the Portland cement-based specimens with perlite added were considered as an insulation material, and a series of compressive tests were conducted to observed the changes in strength due to the numbers of CFRP wrapping layers. A theoretical peak strength model for CFRP-confined concretes was proposed by Li et al. [7]. The peak strength model is expressed as follows:

$$
{f^{\prime}}_{c c}={f^{\prime}}_{c}+{f^{\prime}} \tan ^{2}\left(45^{\circ}+\frac{\varnothing}{2}\right),
$$

where

$$
\begin{gathered}
f^{\prime}{ }_{l}=\frac{2 \times n \times t \times E_{c f} \times \varepsilon_{c f} \times k_{c}}{D}, \\
\varnothing=36^{\circ}+1^{\circ}\left(\frac{f^{\prime}{ }_{c}}{35}\right) \leq 45^{\circ} .
\end{gathered}
$$

In Equation (1), $f^{\prime}{ }_{c c}$ and $f^{\prime}{ }_{c}$ are the confined and unconfined concretes for the compressive strength, respectively, $f^{\prime}$ l stands for the effective lateral confined stress of CFRP, and $\phi$ is the internal friction angle of concretes. In Equation (2), $n$ is the number of layers of CFRP, $t$ is the thickness of the single CFRP layer, $E_{c f}$ is the elastic modulus of CFRP, $\varepsilon_{c f}$ is the strain of CFRP measured at the CFRP-confined concretes, and $k_{c}$ is a sectional shape factor.

To investigate the performance of CFRP confinement, the effective lateral confined stress of CFRP was obtained using Equation (2). For one layer, two layers, and three layers of CFRP wrapping, the effective lateral confined stresses $\left(f_{l}^{\prime}\right)$ were $7.84 \mathrm{MPa}, 15.68 \mathrm{MPa}$, and $23.51 \mathrm{MPa}$, respectively. The measured strains of CFRP-confined specimens are listed in Table 10; we set $\varepsilon_{c f}=1.0 \%$ in the calculation.

Table 10. The measured strains of CFRP-confined specimens.

\begin{tabular}{cccc}
\hline Strain & $\begin{array}{c}\text { 1-Layer CFRP } \\
\text { CPCC0-1 }\end{array}$ & $\begin{array}{c}\text { 2-Layer CFRP } \\
\text { CPCC0-2 }\end{array}$ & $\begin{array}{c}\text { 3-Layer CFRP } \\
\text { CPCC0-3 }\end{array}$ \\
\hline & 0.89 & 1.09 & 1.22 \\
Measured strain (\%) & 0.97 & 1.07 & 1.17 \\
& 1.18 & 1.12 & 1.15 \\
\hline Average strain (\%) & 0.01020 & 1.10 & 1.18 \\
\hline
\end{tabular}

The perlite was added to the cement-based specimens as a porous material, which led to a lower strength than that of normal concretes; thus, the internal friction angle needed to be modified. Equation (3) was then modified as follows: 


$$
\varnothing=A^{\circ}+B^{\circ} \times\left(\frac{f^{\prime}{ }_{c}}{{f^{\prime}{ }_{l}}}\right) \leq 45^{\circ},
$$

where $f^{\prime} d f_{l}^{\prime}$ and $\phi$ are used as the horizontal and vertical axes of coordinates; the theoretical angle of internal friction can then be obtained utilizing a regressive analysis method. Subsequently, the theoretical compressive peak strength of the confined specimens was obtained by substituting the internal friction angle $(\phi)$ into Equation (1).

To find the angle of internal friction, Equation (1) was modified as follows:

$$
\frac{f^{\prime}{ }_{c c}}{f^{\prime}{ }_{c}}=1+\frac{f^{\prime}{ }_{l}}{f^{\prime}{ }_{c}} \times \tan ^{2}\left(45^{\circ}+\frac{\varnothing}{2}\right),
$$

where $f^{\prime} / f^{\prime}{ }_{c}$ and $f_{c c}^{\prime} / f_{c}^{\prime}$ are used as the horizontal and vertical axes of coordinates shown in Figure 11, and then the internal friction angle can be obtained utilizing the regression analysis method. Figure 11a shows the results of the insulation material specimens wrapped by one-layer CFRP. From the regression analysis result, the experimental value of the internal friction angle was $27.9^{\circ}$. Figure $11 \mathrm{~b}, \mathrm{c}$ show the regression analysis results and indicate that the friction angles of the specimens wrapped by two-layer and three-layer CFRP were $20.7^{\circ}$ and $12.0^{\circ}$, respectively. The internal friction angles of the model are shown in Table 11.

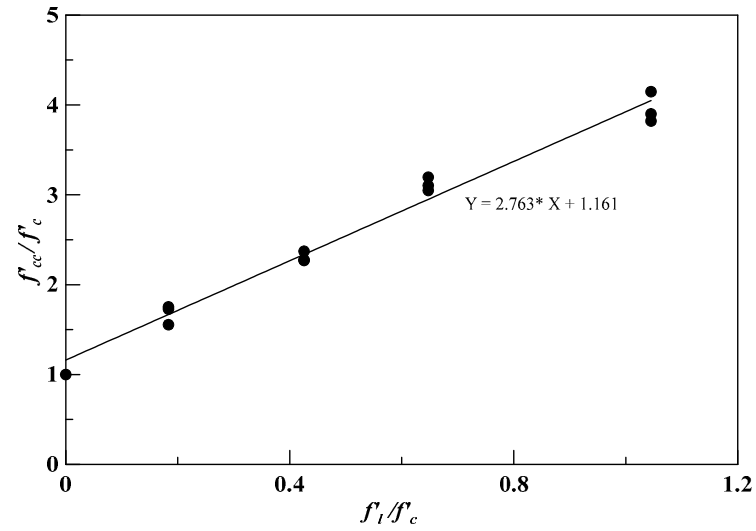

(a)

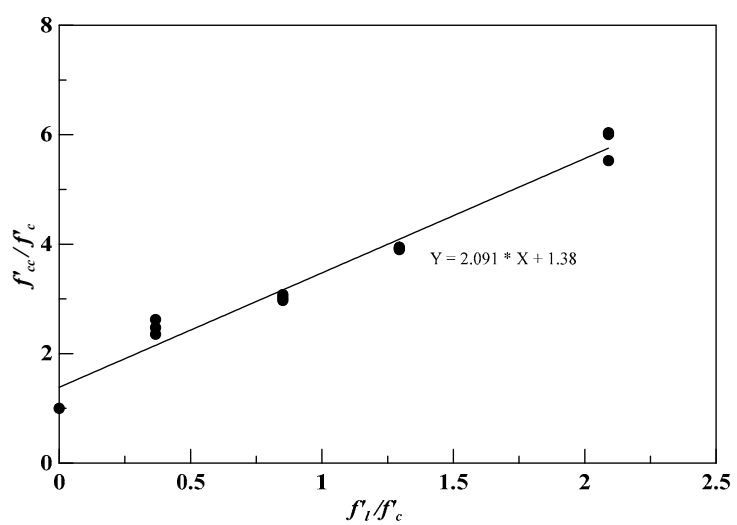

(b)

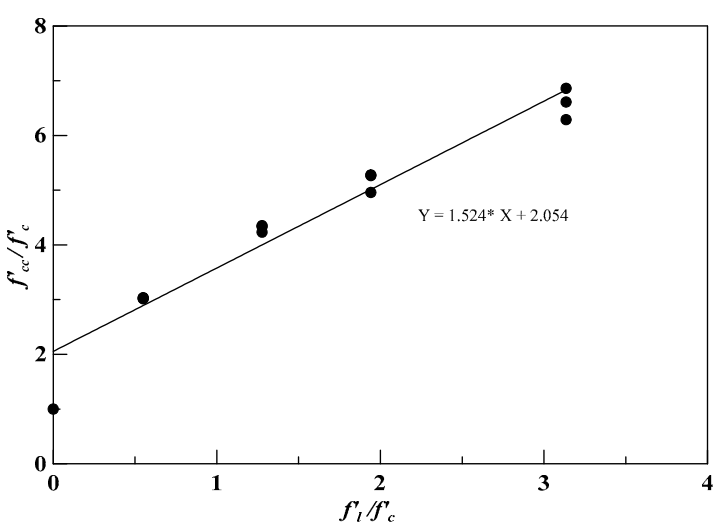

(c)

Figure 11. Regression analysis of the experimental data for determination of internal friction angle of CFRP-confined specimens, (a) one-layer CFRP; (b) two-layer CFRP; (c) three-layer CFRP. 
Table 11. The internal friction angles of the model from regression analysis.

\begin{tabular}{cccc}
\hline Material Parameters & 1-Layer CFRP & 2-Layer CFRP & 3-Layer CFRP \\
\hline$f^{\prime}{ }_{l}(\mathrm{MPa})$ & 7.84 & 15.67 & 23.51 \\
Internal friction angle $(\phi)$ & 27.9 & 20.7 & 12.0 \\
\hline
\end{tabular}

In Equation (4), $f^{\prime} d f^{\prime} l$ values were obtained from Table 12, and $\phi$ values are shown in Table 11, which were then used as the horizontal and vertical axes of coordinates. By using the regression analysis, the coefficients $A$ and $B$ in Equation (4) could be obtained as 16.46 and 2.37, respectively. Equation (4) was rewritten as follows:

$$
\varnothing=16.46^{\circ}+2.37^{\circ}\left(\frac{{f^{\prime}}_{c}}{{f^{\prime}}_{l}}\right) \leq 45^{\circ} .
$$

Table 12. The $f^{\prime} d f^{\prime} l$ values for different perlite ratios and confined by different numbers of layers of CFRP.

\begin{tabular}{cccccc}
\hline- & - & \multicolumn{3}{c}{ Perlite Ratio in Weight } \\
\hline- & No. of CFRP Layers & $\mathbf{0 \%}$ & $\mathbf{1 0 \%}$ & $\mathbf{2 0 \%}$ & $\mathbf{3 0} \%$ \\
\hline \multirow{2}{*}{$\frac{f_{c}^{\prime}}{f_{l}^{\prime}}$ Value } & 1 & 5.45 & 2.35 & 1.55 & 0.96 \\
& 2 & 2.73 & 1.18 & 0.77 & 0.48 \\
& 3 & 1.82 & 0.78 & 0.52 & 0.32 \\
\hline
\end{tabular}

The theoretical compressive peak strengths of specimens confined by CFRP were obtained by substituting the corresponding internal friction angle into Equation (1). Table 13 lists the experimental and the proposed theoretical compressive peak strengths and their percentage errors, where the average absolute error was found to be $9.48 \%$. Figure 12 shows the deviation between the theoretical and experimental compressive peak strengths, and the correlation coefficient $\left(R^{2}\right)$ was equal to 0.9 . The results show that the proposed theoretical compressive peak strength model could predict the experimental compressive peak strength with good accuracy.

Table 13. Comparison between experimental and proposed theoretical compressive peak strengths.

\begin{tabular}{ccccc}
\hline Specimen & $\begin{array}{c}\text { Number of CFRP } \\
\text { Layers }\end{array}$ & $\begin{array}{c}\text { Average Experimental } \\
\text { Compressive Peak } \\
\text { Strength (MPa) }\end{array}$ & $\begin{array}{c}\text { Theoretical } \\
\text { Compressive Peak } \\
\text { Strength (MPa) }\end{array}$ & $\begin{array}{c}\text { Absolute Error } \\
\text { (\%) }\end{array}$ \\
\hline CPCC0_1 & 1 & 71.76 & 74.78 & 4.67 \\
CPCC10_1 & 1 & 42.48 & 40.17 & 5.39 \\
CPCC20_1 & 1 & 37.73 & 31.90 & 15.43 \\
CPCC30_1 & 1 & 29.67 & 25.99 & 12.30 \\
CPCC0_2 & 2 & 106.18 & 88.26 & 16.72 \\
CPCC10_2 & 2 & 55.71 & 56.34 & 1.58 \\
CPCC20_2 & 2 & 47.51 & 48.32 & 1.72 \\
CPCC30_2 & 2 & 43.92 & 104.04 & 19.75 \\
CPCC0_3 & 3 & 129.32 & 72.81 & 8.20 \\
CPCC10_3 & 3 & 79.33 & 64.86 & 3.73 \\
CPCC20_3 & 3 & 62.58 & 59.10 & 19.77 \\
CPCC30_3 & 3 & 49.40 &
\end{tabular}




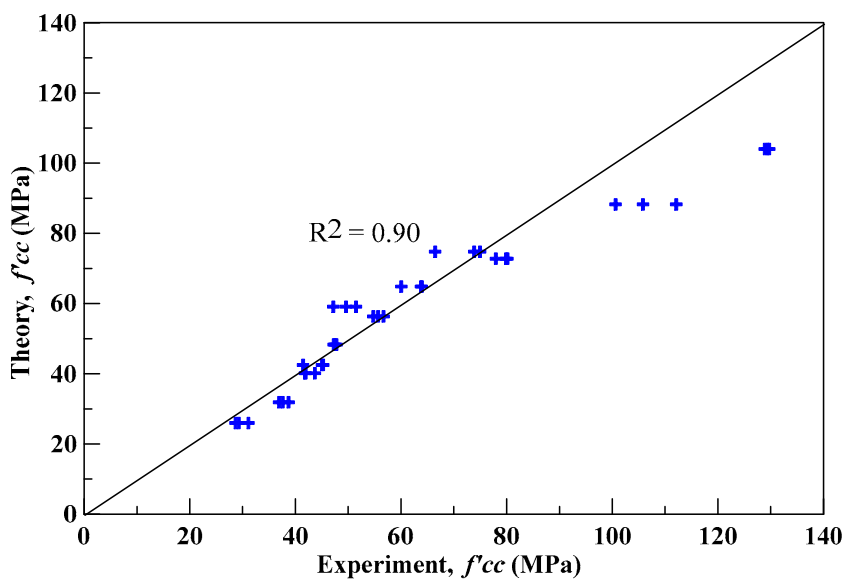

Figure 12. The deviation of theoretical and experimental compressive strengths of confined specimens.

\subsection{A Peak Strength Model for Insulation Material under Elevated Temperature}

The proposed peak strength model for cement-based insulation materials under elevated temperature is provided below.

$$
f^{\prime}{ }_{T}=f_{c}^{\prime} \times e^{-\lambda\left(T-T_{r e f}\right)},
$$

where $f_{T}^{\prime}$ is the compressive peak strength of the insulation material under elevated temperature $(T), f_{c}^{\prime}$ is the compressive peak strength at reference temperature $\left(T_{r e f}\right)$, where $T_{\text {ref }}$ is the reference (room) temperature, and $\lambda$ is the thermal softening parameter of the insulation materials with different perlite ratios.

The thermal softening parameter for each insulation material with different perlite ratios was determined by conducting a regression analysis on the compressive peak strength under different elevated temperatures. For the material parameters for partial replacement of cement with expanded perlite, the results of the regression analysis are shown in Figure 13, where $f_{c}^{\prime}$ and $\Delta T=T-T_{\text {ref }}$ were set as the horizontal and vertical axes of coordinates. The thermal softening parameters of the insulation materials with different perlite ratios are shown in Table 14.

Table 14. Compression test results of unconfined specimens under various temperature.

\begin{tabular}{cccccc}
\hline \multirow{2}{*}{$\boldsymbol{*}$} & $\boldsymbol{\Delta} \boldsymbol{T}={ }^{\circ} \mathbf{C}$ & \multicolumn{3}{c}{ Perlite Ratio in Weight (\%) } \\
\cline { 3 - 6 } & & $\mathbf{0}$ & $\mathbf{1 0}$ & $\mathbf{2 0}$ & $\mathbf{3 0}$ \\
\hline & 0 & 55.25 & 29.33 & 22.70 & 19.29 \\
Average compressive & 75 & 47.02 & 26.86 & 19.86 & 18.17 \\
peak strength $(\mathrm{MPa})$ & 125 & 41.7 & 25.83 & 18.89 & 17.30 \\
& 225 & 39.13 & 23.15 & 17.38 & 16.2 \\
& 275 & 36.65 & 21.3 & 16.25 & 14.24 \\
Material parameter $(\lambda)$ & - & 33.87 & 18.48 & 14.65 & 11.42 \\
\hline
\end{tabular}

Subsequently, the obtained $\lambda$ in Table 14 was substituted into Equation (7) to compute the theoretical compressive peak strength of the insulation materials with different perlite ratios in weight. Table 15 lists the absolute errors between the theoretical and experimental compressive peak strengths; the average absolute errors were $2.81 \%, 3.71 \%, 2.37 \%$, and $6.95 \%$ for perlite ratios of $0 \%, 10 \%, 20 \%$, and $30 \%$, respectively. Figure 14 shows the deviation of the theoretical and experimental compressive peak strengths, and all the correlation coefficients $\left(R^{2}\right)$ were between 0.92 and 0.98 . The results show that the proposed theoretical compressive peak strength model, shown in Equation (7), could predict the experimental compressive peak strength with good accuracy. 


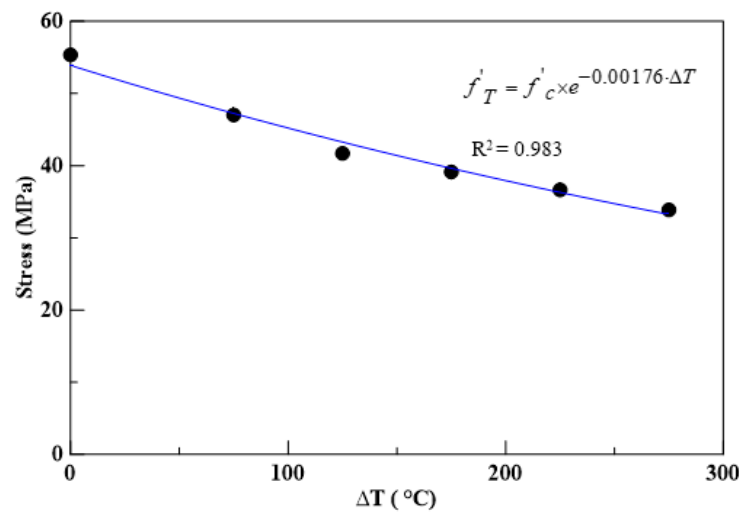

(a)

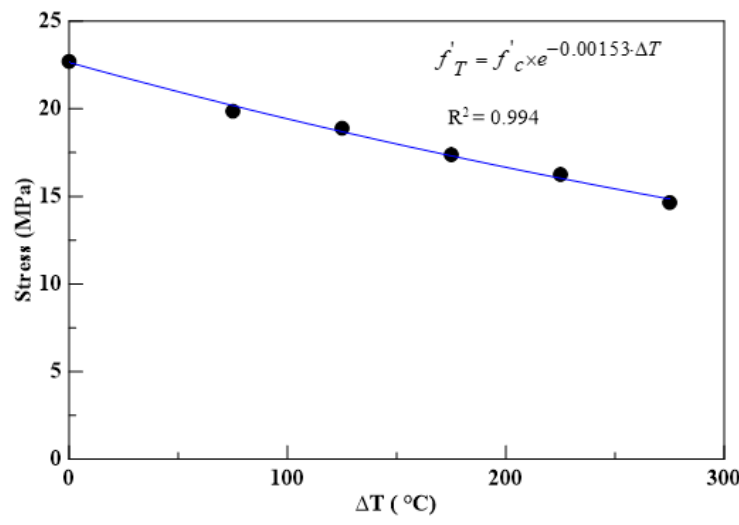

(c)

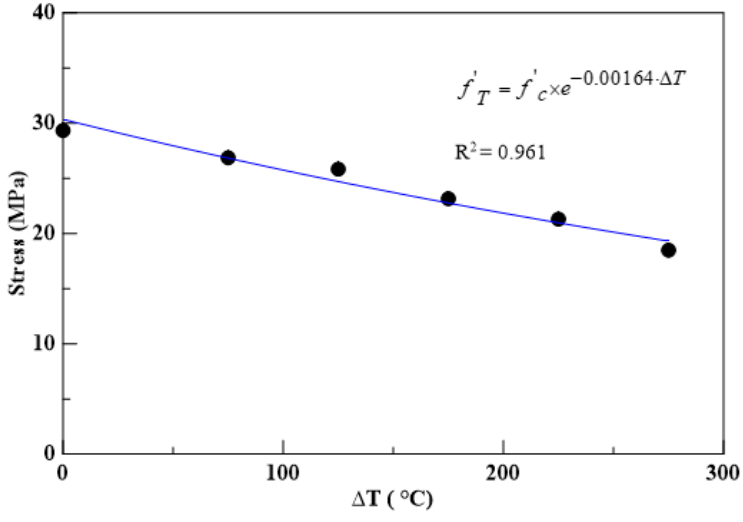

(b)

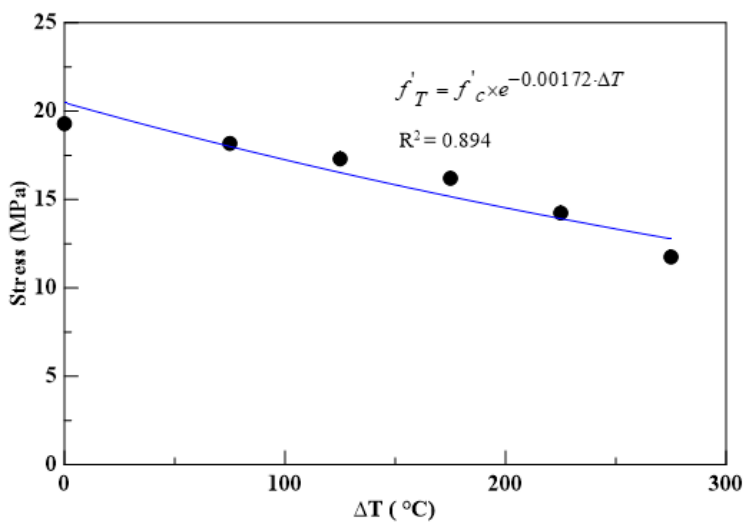

(d)

Figure 13. The regression analysis results of the material parameter of CPC with $0 \%, 10 \%, 20 \%$, and $30 \%$ perlite, (a) $0 \%$ perlite; (b) $10 \%$ perlite; (c) $20 \%$ perlite; (d) $30 \%$ perlite.

Table 15. Absolute errors between experimental and theoretical results.

\begin{tabular}{cccccc}
\hline & $\boldsymbol{\Delta} \boldsymbol{T}\left({ }^{\circ} \mathbf{C}\right)$ & \multicolumn{4}{c}{ Perlite Ratio in Weight (\%) } \\
\cline { 3 - 6 }- & & $\mathbf{0}$ & $\mathbf{1 0}$ & $\mathbf{2 0}$ & $\mathbf{3 0}$ \\
\hline & 0 & 0 & 0 & 0 & 0 \\
Absolute error $(\%)$ & 125 & 3.16 & 3.43 & 1.90 & 6.69 \\
& 175 & 6.51 & 7.51 & 1.64 & 10.01 \\
& 225 & 2.96 & 4.85 & 3.78 & 11.72 \\
& 275 & 0.99 & 4.80 & 1.53 & 7.71 \\
Average absolute error $(\%)$ & - & 2.81 & 3.71 & 2.37 & 6.95 \\
\hline Correlation coefficient $\left(R^{2}\right)$ & - & 0.96 & 0.97 & 0.98 & 0.92 \\
\hline
\end{tabular}




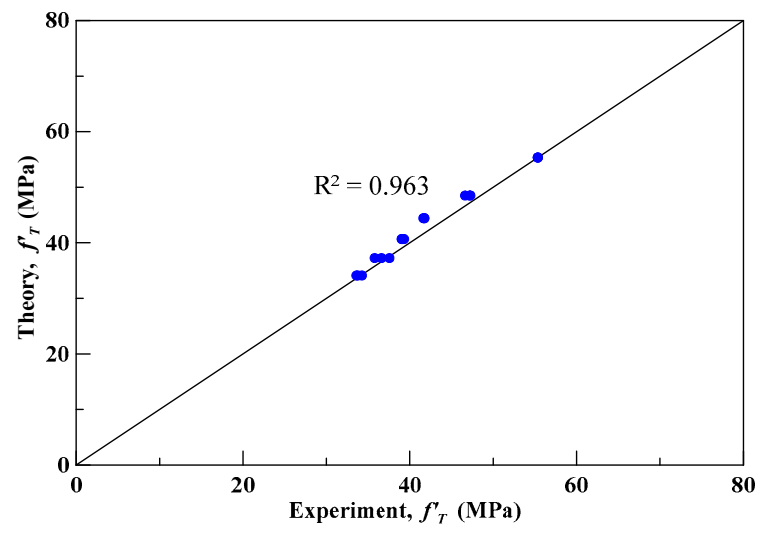

(a)

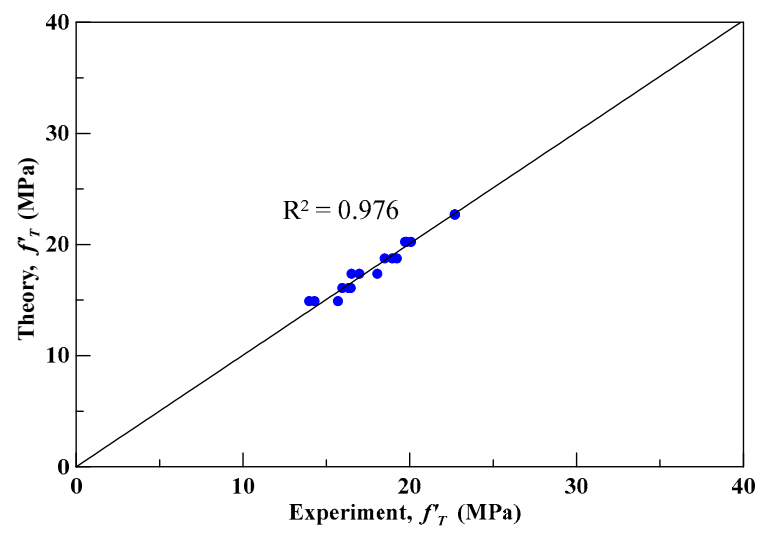

(c)

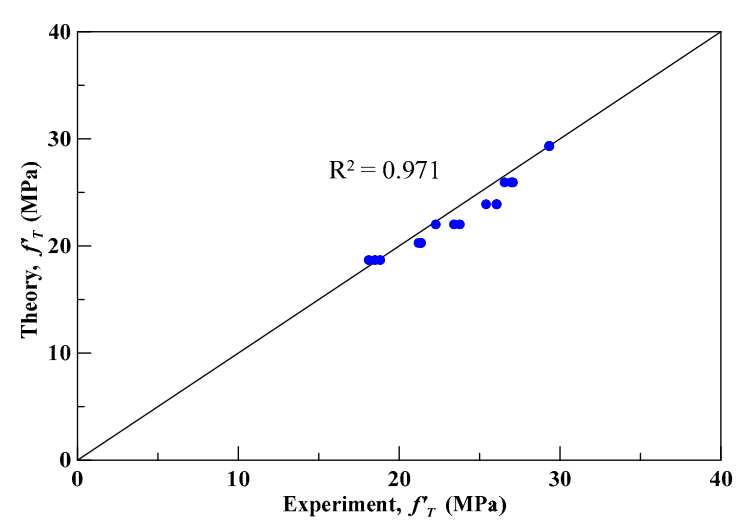

(b)

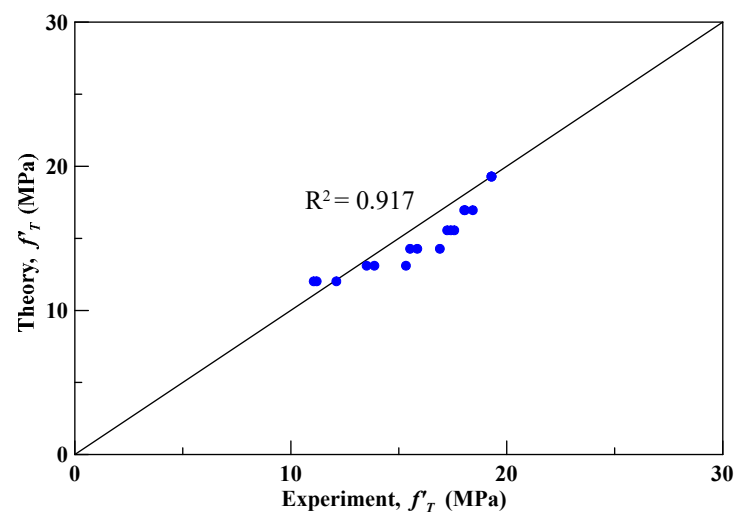

(d)

Figure 14. The deviation of theoretical and experimental compressive strengths of OPC specimens with $0 \%, 10 \%, 20 \%$, and $30 \%$ perlite under elevated temperature, (a) $0 \%$ perlite; (b) $10 \%$ perlite; (c) $20 \%$ perlite; (d) $30 \%$ perlite.

\subsection{A Peak Strength Model for CFRP-Confined Insulation Material under Elevated Temperature}

For the peak strength model for CFRP-confined insulation material, the average absolute error between the theoretical and experimental peak strength results was $9.48 \%$, and the correlation coefficient of experimental and theoretical results was 0.9 . For the peak strength model for insulation material under elevated temperature, the average absolute errors between the theoretical and experimental peak strength results were between $2.37 \%$ and $6.95 \%$, and the correlation coefficients $\left(R^{2}\right)$ were between 0.92 and 0.98. Thus, a peak strength model of CFRP-confined specimens under elevated temperature was developed by combining the compressive strength characteristics of the unwrapped specimens under elevated temperature and of the CFRP-wrapped specimens at room temperature. The physical-based peak strength model for CFRP-confined insulation material under elevated temperature is provided as follows:

$$
{f^{\prime}}_{T c \mathcal{C}}={f^{\prime}}_{c \mathcal{C}} \times e^{-\lambda\left(T-T_{r e f}\right)},
$$

where $f^{\prime} T_{c c}$ is the compressive strength of CFRP-confined specimens under elevated temperatures, $f_{c c}^{\prime}$ is the compressive strength of CFRP-confined specimens shown in Equation (1), and $\lambda$ is the thermal softening parameter. Equation (8) provides an alternative approach for prediction of the compressive strength of CFRP-confined specimens under elevated temperatures.

\section{Conclusions}

Regression analysis was used for predicting the compressive strength of thermal insulation specimens with and without CFRP wrapping using three variables, namely, the cement-perlite ratio in 
weight, elevated temperatures of the concrete, and the number of CFRP confined layers. Based on the results of this study, the following conclusions can be drawn:

1. From the test results, it is found that the compressive strength of Portland cement diminished with an increase in the addition of perlite.

2. In the compression tests under elevated temperatures, it was observed that the compressive strength of the insulation material specimens decreased with an increase in temperature.

3. In the compression tests of CFRP-confined specimens, it was found that a lower original compressive strength led to a higher strength enhancement percentage after the application of CFRP confinement. For the insulation material specimens with one-layer CFRP wrapping, the strength was 3.96 times higher than for unwrapped specimens. For the two-layer and three-layer CFRP-confined specimens, the compressive strength was 5.86 and 6.65 times higher than for unwrapped specimens. A higher number of layers of CFRP wrapping led to a higher percentage of compressive peak strength.

4. For the peak strength model for CFRP-confined insulation material, the average absolute error between the theoretical and experimental peak strength results was $9.48 \%$, and the correlation coefficient of experimental and theoretical results was 0.9 .

5. For the peak strength model for insulation material under elevated temperature, the average absolute errors between the theoretical and experimental peak strength results were between $2.37 \%$ and $6.95 \%$, and the correlation coefficients $\left(R^{2}\right)$ were between 0.92 and 0.98 .

Author Contributions: Conceptualization, Y.-F.L.; data curation, W.-K.S.; formal analysis, W.-K.S.; investigation, W.-K.S. and Y.-K.T.; methodology, Y.-F.L. and Y.-K.T.; project administration, Y.-F.L.; supervision, Y.-F.L.; writing-original draft, W.-K.S. and Y.-K.T.; writing-review and editing, Y.-F.L. and Y.-K.T. All authors have read and agreed to the published version of the manuscript.

Funding: This research was funded by the Ministry of Science and Technology of Taiwan government, under contract No. MOST-106-2221-E-027-047, and the "Research Center of Energy Conservation for New Generation of Residential, Commercial, and Industrial Sectors" from the Ministry of Education in Taiwan.

Conflicts of Interest: The authors declare no conflict of interest.

\section{References}

1. Li, Y.F.; Yang, T.H.; Tsai, T.H. A novel strengthening method for damaged pipeline under high temperature using inorganic insulation material and carbon fiber reinforced plastic composite material. Materials 2019, 12, 3484. [CrossRef] [PubMed]

2. Ergün, A.; Kürklü, G.; Başpınar, M.S.; Mansour, M.Y. The effect of cement dosage on mechanical properties of concrete exposed to high temperatures. Fire Saf. J. 2013, 55, 160-167. [CrossRef]

3. Ramezanianpour, A.A.; Karein, S.M.M.; Vosoughi, P.; Pilvar, A.; Isapour, S.; Moodi, F. Effects of calcined perlite powder as a SCM on the strength and permeability of concrete. Constr. Build. Mater. 2014, 66, 222-228. [CrossRef]

4. Tasdemir, C.; Sengul, O.; Tasdemir, M.A. A Comparative study on the thermal conductivities and mechanical properties of lightweight concretes. Energy Build. 2017, 151, 469-475. [CrossRef]

5. Sengul, O.; Azizi, S.; Karaosmanoglu, F.; Tasdemir, M.A. Effect of expanded perlite on the mechanical properties and thermal conductivity of lightweight concrete. Energy Build. 2011, 43, 671-676. [CrossRef]

6. Huang, Z.; Liew, J.Y.R.; Li, W. Evaluation of compressive behavior of ultra-lightweight cement composite after high temperature exposure. Constr. Build. Mater. 2017, 148, 579-589. [CrossRef]

7. Li, Y.F.; Lin, C.T.; Sung, Y.Y. A constitutive model for concrete confined with carbon fiber reinforced plastics. Mech. Mater. 2003, 35, 603-619. [CrossRef]

8. Hoshikuma, J.; Kawashima, K.; Nagaya, K.; Taylor, A.W. Stress-strain model for confined concrete in bridge piers. J. Struct. Eng. ASCE 1997, 123, 624-633. [CrossRef]

9. Kent, D.C.; Park, R. Flexural members with confined concrete. J. Stru. Div. ASCE 1971, 97, 1969-1990.

10. Mander, J.B.; Priestley, M.J.N.; Park, R. Theoretical stress-strain model for confined concrete. J. Stru. Div. ASCE 1988, 114, 1804-1826. [CrossRef] 
11. Mander, J.B.; Priestley, M.J.N.; Park, R. Observed stress-strain behavior of confined concrete. J. Stru. Div. ASCE 1988, 114, 1969-1990. [CrossRef]

12. Al-Salloum, Y.A.; Elsanadedy, H.M.; Abadel, A.A. Behavior of FRP-confined concrete after high temperature exposure. Constr. Build. Mater. 2011, 25, 838-850. [CrossRef]

13. Micelli, F.; Modarelli, R. Experimental and analytical study on properties affecting the behavior of FRP-confined concrete. Compos. Part B 2013, 45, 1420-1431. [CrossRef]

14. Saeed, H.Z.; Khan, Q.U.Z.; Khan, H.A.; Farooq, R. Experimental investigation of stress-strain behavior of CFRP confined low strength concrete (LSC) cylinders. Constr. Build. Mater. 2016, 104, 208-215. [CrossRef]

15. Topçu, I.B.; Işıkdağ, B. Manufacture of high heat conductivity resistant clay bricks containing perlite. Build. Environ. 2016, 42, 3540-3546. [CrossRef]

16. Topçu, I.B.; Işıkdağ, B. Effect of expanded perlite aggregate on the properties of lightweight concrete. J. Mater. Process. Techno. 2008, 204, 34-38. [CrossRef]

17. Demirboğa, R.; Örüng, İ.; Gül, R. Effect of expanded perlite aggregate and mineral admixtures on the compressive strength of low-density concretes. Cem. Concr. Res. 2001, 31, 1627-1632. [CrossRef]

18. Wongkeo, W.; Thongsanitgarn, P.; Pimraksa, K.; Chaipanich, A. Compressive strength flexural strength and thermal conductivity of autoclaved concrete block made using bottom ash as cement replacement materials. Mater. Des. 2012, 35, 434-439. [CrossRef]

19. Oktay, H.; Yumrutaş, R.; Akpolat, A. Mechanical and thermophysical properties of lightweight aggregate concretes. Constr. Build. Mater. 2015, 96, 217-225. [CrossRef]

20. Ma, Q.; Guo, R.; Zhao, Z.; Lin, Z.; He, K. Mechanical properties of concrete at high temperature - a review. Constr. Build. Mater. 2015, 93,371-383. [CrossRef]

21. Trapko, T. The effect of high temperature on the performance of CFRP and FRCM confined concrete elements. Compos. Part B 2013, 54, 138-145. [CrossRef]

22. Lim, J.C.; Ozbakkaloglu, T. Influence of concrete age on stress-strain behavior of FRP-confined normal-and high-strength concrete. Constr. Build. Mater. 2015, 82, 61-70. [CrossRef]

23. Berthet, J.F.; Ferrier, E.; Hamelin, P. Compressive behavior of concrete externally confined by composite jackets. Part A: Experimental study. Constr. Build. Mater. 2005, 19, 223-232. [CrossRef]

24. Belouar, A.; Laraba, A.; Benzaid, R.; Chikh, N. Structural performance of square concrete columns wrapped with CFRP sheets. Procedia Eng. 2013, 54, 232-240. [CrossRef]

25. Zhou, J.; Bi, F.; Wang, Z.; Zhang, J. Experimental investigation of size effect on mechanical properties of carbon fiber reinforced polymer (CFRP) confined concrete circular specimens. Constr. Build. Mater. 2016, 127, 643-652. [CrossRef]

26. Wootton, I.; Spainhour, L.; Yazdani, N. Corrosion of steel reinforcement in carbon fiber-reinforced polymer wrapped concrete cylinders. J. Compos. Constr. 2003, 7, 339-347. [CrossRef]

27. ASTM C39/C39M-18. Standard Test. Method for Compressive Strength of Cylindrical Concrete Specimens; ASTM: West Conshohocken, PA, USA, 2018.

28. ASTM C109/C M109-02. Standard Test. Method for Compressive Strength of Hydraulic Cement Mortars; ASTM: West Conshohocken, PA, USA, 2016.

(C) 2019 by the authors. Licensee MDPI, Basel, Switzerland. This article is an open access article distributed under the terms and conditions of the Creative Commons Attribution (CC BY) license (http://creativecommons.org/licenses/by/4.0/). 